\title{
100KW Rooftop Solar Photovoltaic Power Plant: Block "B" of Ahsanullah University of Science and Technology
}

\author{
Maskura Nafreen ${ }^{1}$, Md.Ibrahim Hossen ${ }^{2}$, Ashiqur Rahman ${ }^{3}$, Rakibul Islam ${ }^{4}$, \\ Zannatul Ferdous ${ }^{5}$ Md Sabbir Hasan Sohag ${ }^{6}$ \\ ${ }^{I}$ (Department of Electrical and Electronic Engineering, Ahsanullah University of Science and Technology, \\ Bangladesh) \\ ${ }_{2}^{2}$ (Department of Electrical and Electronic Engineering, Ahsanullah University of Science and Technology, \\ Bangladesh) \\ ${ }^{3}$ (Department of Electrical and Electronic Engineering, Ahsanullah University of Science and Technology, \\ Bangladesh) \\ ${ }^{4}$ (Department of Electrical and Electronic Engineering, Ahsanullah University of Science and Technology, \\ Bangladesh) \\ ${ }^{5}$ (Department of Electrical and Electronic Engineering, Ahsanullah University of Science and Technology, \\ Bangladesh) \\ ${ }^{6 /}$ Department of Electrical and Electronic Engineering, Ahsanullah University of Science and Technology, \\ Bangladesh)
}

\begin{abstract}
In Bangladesh, conventional forms of energy are used to generate electricity but at contrast renewable sources of energy should be used because industrialization has caused degradation of environment which affects the consumption of energy sources at great extent. In this paper, a renewable source is proposed named "Photovoltaic power" which will be used to design a system of electricity generation at the rooftop of ahsanullah University of science and technology (Block-b). Design procedures, cost estimation of grid connected to power plant, calculations are described here.
\end{abstract}

Keyword: Renewable energy, photovoltaic energy, solar power, location analysis, capacity calculation, autocad, sunny design web.

\section{Introduction}

When power quality problems arise because of the existed local generation of energy, adoption of new renewable energy becomes necessary. This paper deals with the use and design of photovoltaic system which will be used for an area of 6,000 ft square.[3]Photovoltaic process means production of electricity directly from sunlight where photovoltaic cells are used to interact with the sunlight with internal semiconductor materials.[4]For design layout and calculations for getting practical data and location analyzing "AutoCAD" and "Sunny Design" software are used[5][6] and estimated cost calcula is attached.[2]

\section{Methods}

For system installation at the certain area of the rooftop, cells have to be connected with south facing tilt angle of 30 degrees considering 23.8035 latitude.[7]

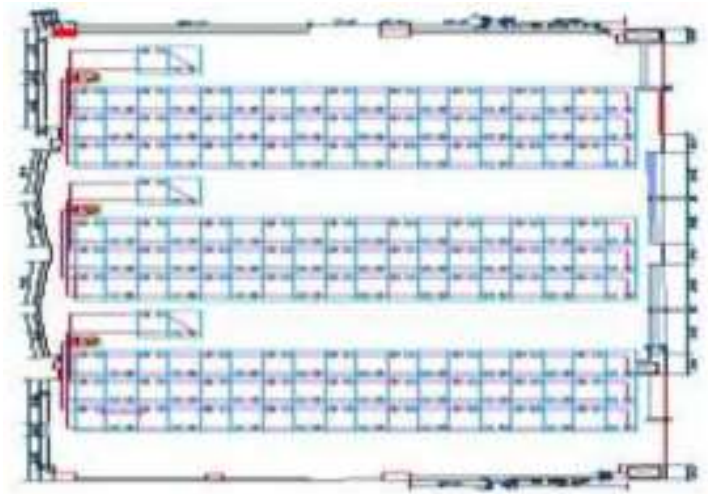

Fig. 1 Design Layout of Ahsanullah university Block rooftop by AutoCAD. 


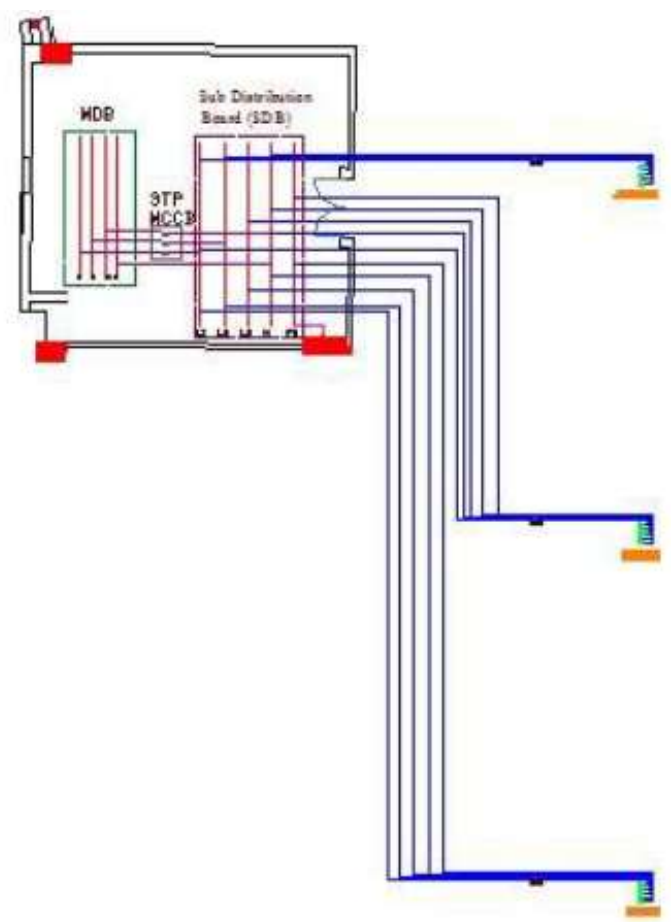

Fig. 2 Design Layout of Ahsanullah university Block rooftop(inverter to MDB ) by AutoCAD .

For servicing purpose, distance between panels and parapet wall has to be $5 \mathrm{ft}$. Building loads are connected to photovoltaic grid and inverter is placed outside.[1]Surplus energy is fed back to grid for night or bad weather condition. Bidirectional type service connection meter is needed.[8]

\section{Findings And Argument}

By using ,sunny design ${ }^{\text {ee }}$ software we have achieved the following data:

Azimuth Angle 0 Tilt Angle 23 mounting type: Roof

PV design data (Headings)

Total number of PV modules- 168

Peak power- $48.12 \mathrm{kwp}$

Number of PV inverter -3

Nominal AC power of the PV inverter $-45.00 \mathrm{KW}$

AC Active power $-45.00 \mathrm{KW}$

Active power ratio $-92.4 \%$

Annual energy yield* ${ }^{*} 81,950.50 \mathrm{KWh}$

Energy usability factor $-100 \%$

Performance ratio $-87.2 \%$

Specific energy yield $-1682 \mathrm{kwh} / \mathrm{kwp}$

Line losses(in \% of PV energy):

Unbalanced load: $0.00 \mathrm{VA}$

The required no of PV modules $=168$ which has to be accommodate within the free space of the rooftop of about $6,000 \mathrm{ft} 2$

The entire design can sectionalize in one part.

The specifications of section 1 are given below $3 \times$ STP15000TL-30

Peak power: $48.72 \mathrm{KWp}$

Total number of PV modules: 168

No of PV inverter: 3

Maximum DC power: $15.33 \mathrm{KW}$

Maximum AC active power: $15.00 \mathrm{KW}$

Grid voltage: $230 \mathrm{~V}$ (230/400V)

Nominal power ratio: $94 \%$

Dimensioning factor: $106 \%$

Displacement power factorcos $\varnothing$ : 1 
100KW Rooftop solar photovoltaic Power Plant: Block “B” of Ahsanullah University Of Science ..

Table 1: Financial overview

\begin{tabular}{|l|l|l|l|l|}
\hline No & Equipment's & Quantity & Unit price & Price \\
\hline 1 & Solar panel & 168 & 65 th/wat & 31.66800 \\
\hline 2 & Inverter & 3 & 4.75000 & 14.25000 \\
\hline 3 & Cable & $426 \mathrm{~min}$ & & 56,564 \\
\hline 4 & MCCB & 4 piece & 16000 & 64,000 \\
\hline 5 & MDB & & & 60,000 \\
\hline 6 & Potental Earthing & & 1,00000 \\
\hline \multicolumn{2}{|c|}{ Total cost $=48,72364$ BDT } & \\
\hline
\end{tabular}

Peak power watts, $P \max =290 \mathrm{Wp}$

No of solar panels $=\mathrm{X}$

$\mathrm{Y}=\mathrm{X} \times$ Space factor

Here , Space factor is 0.9

So, The Plant Capacity $=\mathrm{Y} \times \mathrm{P} \max$

The Energy $=\frac{\text { Plant Capacity } \times \text { Plant efficiency }}{\text { Operating Time }}$ (unit : Kwh/day)

Here Operating Time $=4.5$ hours per day

Plant Efficiency $=85 \%$

In our Design,

No of solar panels, $\mathrm{X}=168$

$\mathrm{Y}=\mathrm{X} \times$ Space factor

$=168 \times 0.9$

$=151.2$

Plant Capacity $=\mathrm{Y} \times \mathrm{P} \max$

$$
\begin{aligned}
& =(151.2 \times 290 W p) \\
= & 43.848 k W p \approx 44 k W p
\end{aligned}
$$

The Energy $=\frac{\text { Plant Capacity } \times \text { Plant efficiency }}{\text { Operating Time }}$ (unit : Kwh/day)

\section{Per Watt Cost}

$$
\begin{aligned}
& \frac{44 \times 0.85}{4.5} \mathrm{Kwh} / \text { day } \\
& =8.31 \mathrm{Kwh} / \text { day }
\end{aligned}
$$

$$
\begin{aligned}
& =\text { Total Cost } \div \text { Plant Capacity } \\
& =48,72364 \mathrm{BDT} \div 44000 W p \\
& =110.73 \mathrm{BDT} \text { per } W p \approx 111 \mathrm{BDT} \text { per } W p .
\end{aligned}
$$

\section{Conclusion}

Proposed design costs 48,72, 364 BDT and daily energy generation fed into grid is approximately $8.31 \mathrm{kwh} /$ day.The outputs are calculated on the basis of $6,000 \mathrm{ft}$ square area and the methodology of this can be adopted for similar system design and analysis.

\section{References}

[1]. Rachid Errouissi; Ahmed Al-Durra; S. M. Muyeen,” A Robust Continuous-Time MPC of a DC-DC Boost Converter Interfaced With a Grid- Connected Photovoltaic System", IEEE Journal of Photovoltaics, Year: 2016, Volume: 6, Issue: 6.

[2]. C.Aarthy Vigneshwari; S. Siva Sakthi Velan; M. Venkateshwaran; M. Adam Mydeen; V. Kirubakaran, "Performance and economic study of on-grid and offgrid solar photovoltaicsystem", 2016 International Conference on Energy Efficient Technologies for Sustainability (ICEETS), Year: 2016.

[3]. N. Aghli; M. H. Pourarab; S. Alishahi; M. Zabihi; G. Wu, "Economic assessment of solar photovoltaic system for AC/DC lighting circuits", 2015 IEEE International Telecommunications Energy Conference (INTELEC),Year: 2015.

[4]. Xingshuo Li; Huiqing Wen; Lin Jiang; Yihua Hu; Chenhao Zhao, “ An Improved Beta Method With Autoscaling Factor for Photovoltaic System”, IEEE Transactions on Industry Applications Year: 2016, Volume: 52, Issue: 5.

[5]. Zhou Hongbo, "Research on conversion of AutoCAD graphic data to ArcInfo data format", Computer Science \& Education (ICCSE), 2013 8th International Conference on, Year: 2013. 
[6]. K. Harzli; H. Oueslati; A. Ben Mabrouk; S. B. Mabrouk; L. Dusonchet; S. Favuzza; D. La Cascia; F. Massaro; G. Zizzo, "Study and simulation of photovoltaic installation connected to the grid with storage system", 2016 7th International Renewable Energy Congress (IREC), Year: 2016.

[7]. Bertrand Paviet-Salomon; Jacques Levrat; Vahid Fakhfouri; Yanik Pelet; Nicolas Rebeaud; Matthieu Despeisse; Christophe Ballif, "Accurate Determination of Photovoltaic Cell and Module Peak Power From Their Current-Voltage Characteristics", IEEE Journal of Photovoltaics, Year: 2016, Volume: 6, Issue: 6.

[8]. Ritesh Dash; Sarat Chandra Swain; P. C Panda, "A study on the increasing in the performance of a solar photovoltaic cellduring shading condition”, 2016 International Conference on Circuit, Power and Computing Technologies (ICCPCT), Year: 2016. 